\title{
Effects of Hypotonic Saline Loading in Hydrated Dog: Evidence for a Saline-induced Limit on Distal Tubular Sodium Transport*
}

\author{
Richard M. Stein, $\nmid$ Ruth G. Abramson, Thomas Kahn, $\$$ and \\ MARVIN F. LeVITT
}

(From the Section of Renal Diseases, Department of Medicine, The Mount Sinai School of Medicine, New York, N. Y., and the Renal Unit, Medical Service, U. S. Public Health Service Hospital, Staten Island, N. Y.)

\begin{abstract}
Summary. We performed studies on dogs under hydrated conditions, utilizing the rate of free water formation $\left(\mathrm{C}_{\mathrm{H}_{2} \mathrm{O}}\right)$ as an index of the rate of distal tubular sodium transport. Since $\mathbf{C}_{\mathrm{H}_{2} \mathrm{O}}$ could be progressively increased with no evidence of a maximal rate during loading with hypotonic $(2.5 \%)$ mannitol, it was concluded that there is no limit on distal tubular sodium transport during mannitol loading. In contrast, during hypotonic $(0.45 \%)$ saline loading $\mathrm{C}_{\mathrm{H}_{2} \mathrm{O}}$ rose initially, but as urine flow (V) exceeded $25 \%$ of the filtered load $\mathrm{C}_{\mathrm{H}_{2} \mathrm{O}}$ attained maximal levels (up to $20 \%$ of the filtered load) and remained stable as $\mathrm{V}$ increased to $50 \%$ of the filtered load. It was concluded that saline loading progressively inhibits proximal sodium reabsorption. Initially, the distal tubule absorbs a large fraction of the proximal rejectate and sodium excretion rises slightly. Eventually, an alteration in distal sodium transport appears which culminates in a maximal rate or transport limit. This distal transport limit provoked by saline loading could not be characterized by a classical $\mathrm{Tm}$ as seen with glucose and does not seem to be consequent to high rates of flow through the distal tubule. Regardless of the precise nature of this limit, the major increment in sodium excretion develops during saline loading only after saline alters the capacity of the distal tubule to transport sodium.
\end{abstract}

\section{Introduction}

It is well established that saline loading provokes an extensive inhibition of renal tubular sodium reabsorption. On the basis of micropuncture and

\footnotetext{
* Submitted for publication December 7, 1966; accepted April 11, 1967.

These studies were supported by U. S. Public Health Service research grant $\mathrm{HE}-08535$ from the National Heart Institute, and CCIC grant P-67-22 from the Bureau of Health Services, Division of Direct Health Services, U. S. Public Health Service.

Presented in abstract form at the Fifty-Seventh Annual Meeting of the American Society for Clinical Investigation, May, 1965 (J. clin. Invest. 1965, 44, 1100).

† Address requests for reprints to Dr. Richard M. Stein, U. S. Public Health Service Hospital, Staten Island, N. Y. 10304.

$\ddagger$ National Institutes of Health postdoctoral fellow.
}

clearance studies in dog, it was concluded that the inhibition of sodium transport develops primarily within the proximal tubule $(1,2)$. Despite considerable reductions in proximal reabsorption suggested by these studies, sodium excretion remained at relatively low levels $(1,2)$. In contrast, other saline loading studies, in which sodium excretion rose to high levels, suggested that saline provoked a significant inhibition of distal tubular sodium transport $(3,4)$. It is proposed, on the basis of the present data, that hypotonic saline loading in dog provokes a progressive inhibition of proximal tubular sodium reabsorption. Subsequently, an alteration develops in distal reabsorption which culminates in a maximal rate of distal sodium transport. The major increment in sodium excretion apparently develops only after saline load- 
ing alters the capacity for sodium transport in the distal tubule. A maximal rate of distal sodium transport could not be demonstrated during hypotonic mannitol loading.

\section{Methods}

Experiments were performed on mongrel dogs (18 to $25 \mathrm{~kg}$ ) who were fed $10 \mathrm{~g}$ of $\mathrm{NaCl}$ per day for 3 days before each study. Animals were deprived of food for 24 hours before each experiment but received water ad libitum. Anesthesia was instituted with a combination of ethyl carbamate and $\alpha$-chloralose or sodium Pentothol alone and maintained with ethyl carbamate and $\alpha$-chloralose administered intravenously. One dog with diabetes insipidus received no anesthesia. After priming doses of inulin, a sustaining solution containing sufficient inulin to maintain adequate blood levels was infused with a Bowman constant infusion pump. Urine was collected at 10to 30-minute intervals via an indwelling bladder catheter or ureteral catheters introduced into the distal ureters through a midline suprapubic incision. Midperiod blood specimens were obtained at appropriate intervals.

Mannitol studies. Water hydration was induced with an oral water load of $5 \%$ of the body weight administered by nasogastric tube before anesthesia. After anesthesia, $2.5 \%$ glucose in water was infused at $10 \mathrm{ml}$ per minute until a load of approximately $50 \mathrm{ml}$ per $\mathrm{kg}$ body weight had been administered. In several studies the initial oral water load was omitted and hydration was induced by $2.5 \%$ glucose in water administered intravenously. After urine flow had increased and stabilized, a $2.5 \%$ mannitol solution was substituted for the glucose solution and administered at increasing rates until urine flow could no longer be increased. Late in the course of two studies
250 to $500 \mathrm{mg}$ iv of acetazolamide was superimposed on the mannitol diuresis. In other studies a rapid infusion of hypotonic saline $(0.45 \%)$ was superimposed on the mannitol diuresis. Only studies in which the urinary osmolality after water hydration fell below 100 mosm per $\mathrm{kg} \mathrm{H}_{2} \mathrm{O}$ are included.

Saline studies. We utilized three protocols to induce hydration. In eight experiments in the first group, water hydration was induced with a $2.5 \%$ glucose solution infused at $10 \mathrm{ml}$ per minute until urine flow had increased and stabilized. In seven experiments in the second group, hydration was obtained with $0.45 \%$ saline administered at $10 \mathrm{ml}$ per minute until urine flow had increased and stabilized. In seven experiments in the third group, an oral water load of $5 \%$ of the body weight was administered before anesthesia. After anesthesia the protocol followed in the third group was as outlined for the second group. Only studies in which the urinary osmolality after hydration fell below 100 mosm per $\mathrm{kg} \mathrm{H}_{2} \mathrm{O}$ are included.

In all studies, after hydration had been established, hypotonic saline $(0.45 \%)$ was administered at progressively increasing rates. The rate of infusion was adjusted to remain 3 to $5 \mathrm{ml}$ per minute greater than urine flow. Late in the course of several studies acetazolamide $(250$ to $500 \mathrm{mg}$ iv) was superimposed on the saline diuresis. Late in the course of another experiment, intravenous chlorothiazide (200 mg followed by $200 \mathrm{mg}$ per hour) was superimposed on an increasing saline diuresis.

After anesthesia in seven of the experiments, one renal artery was approached retroperitoneally through a flank incision. An open Blalock clamp was positioned around the isolated vessel and secured in place by a multiangle brace. Urine collections were obtained simultaneously from both kidneys throughout each study via ureteral catheters. After completion of surgery, hy-

TABLE I

A typical mannitol loading experiment*

\begin{tabular}{|c|c|c|c|c|c|c|c|c|c|c|c|c|}
\hline Time & V & Uosm & Cosm & $\mathrm{C}_{2} \mathrm{O}$ & Cinulin & $\begin{array}{c}(\mathrm{V} / \mathrm{GFR}) \\
\times 100\end{array}$ & $\begin{array}{c}\left(\mathrm{C}_{\mathrm{H} 2 \mathrm{O}} / \mathrm{GFR}\right) \\
\times 100\end{array}$ & $P_{\mathrm{Na}}$ & $\mathrm{C}_{\mathrm{Na}}$ & $\begin{array}{c}\left(\mathrm{C}_{\mathrm{Na}} / \mathrm{GFR}\right) \\
\times 100\end{array}$ & $\begin{array}{l}\mathrm{C}_{\mathrm{H2O}} \\
+\mathrm{C}_{\mathrm{Na}}\end{array}$ & $\begin{array}{l}{\left[\left(\mathrm{C}_{\mathrm{H}_{2} \mathrm{O}} / \mathrm{GFR}\right)+\right.} \\
\left(\begin{array}{c}\left.\left.\mathrm{C}_{\mathrm{Na}} / \mathrm{GFR}\right)\right] \\
\times 100\end{array}\right.\end{array}$ \\
\hline $\min$ & $m l / m i n$ & $m O s m / k g$ & $m l / m i n$ & $m l / m i n$ & $m l / m i n$ & $\%$ & $\%$ & $m E q / L$ & $m l / m i n$ & $\%$ & $m l / m i n$ & $\%$ \\
\hline 0 & \multicolumn{12}{|c|}{$1,000 \mathrm{ml} \mathrm{H}_{2} \mathrm{O}$ administered via nasogastric tube. } \\
\hline 45 & \multirow{2}{*}{\multicolumn{12}{|c|}{$\begin{array}{l}\text { Primes administered. Constant infusion started: inulin, } 50 \mathrm{mg} / \mathrm{min} \text { in } 0.45 \% \mathrm{NaCl} \text {, at } 1 \mathrm{ml} / \mathrm{min} \text {. } \\
\text { Surgery completed. }\end{array}$}} \\
\hline 105 & & & & & & & & & & & & \\
\hline 105-230 & \multicolumn{12}{|c|}{$2.5 \%$ glucose in water administered at $10 \mathrm{ml} / \mathrm{min}$} \\
\hline $230-240$ & 12.3 & 90 & 3.9 & 8.4 & 73 & 16.8 & 11.5 & 128 & 0.4 & 0.5 & 8.8 & 11.9 \\
\hline 240 & \multicolumn{12}{|c|}{$2.5 \%$ glucose in water discontinued. $2.5 \%$ mannitol in water administered at $15 \mathrm{ml} / \mathrm{min}$. } \\
\hline 240-250 & 13.5 & 95 & 4.5 & 9.0 & 77 & 17.5 & 11.7 & & 0.5 & 0.7 & 9.5 & 12.4 \\
\hline 250 & \multicolumn{12}{|c|}{$2.5 \%$ mannitol in water administered at progressively increasing rates throughout remainder of experiment. } \\
\hline 250-260 & 15.6 & 103 & 5.7 & 10.0 & 74 & 21.0 & 13.4 & 127 & 0.7 & 0.9 & 10.7 & 14.3 \\
\hline $260-270$ & 17.4 & 105 & 6.5 & 10.9 & 73 & 23.8 & 14.9 & & 0.9 & 1.2 & 11.8 & 16.1 \\
\hline $270-280$ & 19.8 & 110 & 7.9 & 12.0 & 70 & 28.3 & 17.1 & 122 & 1.1 & 1.6 & 13.1 & 18.7 \\
\hline $280-290$ & 22.5 & 115 & 9.3 & 13.2 & 70 & 32.1 & 18.8 & & 1.5 & 2.1 & 14.7 & 20.9 \\
\hline $290-300$ & 23.9 & 125 & 10.9 & 13.0 & 68 & 35.1 & 19.1 & 119 & 1.9 & 2.8 & 15.9 & 21.9 \\
\hline $300-310$ & 25.5 & 127 & 11.8 & 13.7 & 78 & 32.6 & 17.5 & & 2.0 & 2.6 & 15.7 & 20.1 \\
\hline $310-320$ & 27.5 & 129 & 12.9 & 14.6 & 74 & 37.2 & 19.8 & 115 & 2.5 & 3.4 & 17.1 & 23.2 \\
\hline $320-330$ & 28.7 & 132 & 13.5 & 15.2 & 82 & 35.1 & 18.6 & & 3.0 & 3.7 & 18.2 & 22.3 \\
\hline $330-340$ & 30.5 & 133 & 14.2 & 16.3 & 70 & 43.6 & 23.3 & 118 & 2.9 & 4.1 & 19.2 & 27.4 \\
\hline $340-350$ & 35.0 & 135 & 16.6 & 18.4 & 80 & 44.0 & 23.1 & 115 & 3.8 & 4.8 & 22.2 & 27.9 \\
\hline
\end{tabular}

* Abbreviations: $\mathrm{V}=$ urine flow; $\mathrm{U}_{\mathrm{osm}}=$ urinary osmolality; $\mathrm{C}_{\mathrm{osm}}, \mathrm{C}_{\mathrm{H}_{2} \mathrm{O}}$, and $\mathrm{C}_{\mathrm{inulin}}=$ solute, free water, and inulin clearances, respectively ; $\mathrm{GFR}=$ glomerular filtration rate $; \mathrm{PNa}^{*}=$ plasma sodium concentration. 
dration was established as described above. After urine flow had increased and stabilized, one renal artery was constricted with the Blalock clamp until a stable reduction in urine flow of 40 to $70 \%$ was produced in the experimental kidney. After one or two additional collection periods had been obtained, hypotonic saline $(0.45 \%)$ was infused at increasing rates.

Urine and plasma specimens were analyzed for osmolality on a Fiske osmometer, for sodium and potassium on a Baird flame photometer, for chloride on a Cotlove automatic titrator, and for inulin by the resorcinol method with alkali treatment (5). The clearance of inulin was utilized to represent glomerular filtration rate (GFR). Solute clearance ( $\mathrm{C}_{\text {osm }}$ ) was calculated as $U_{o s m} V / P_{o s m}$, where $U_{o s m}$ and $P_{o s m}$ represent urine and plasma osmolalities, respectively. $\mathrm{C}_{\mathrm{H}_{2} \mathrm{O}}$ was calculated as $\mathrm{V}-\mathrm{C}_{\mathrm{osm}}$. The clearance of sodium $\left(\mathrm{C}_{\mathrm{Na}_{\mathrm{a}}}\right)$ was calculated at $U_{\mathrm{Na}} V / \mathrm{P}_{\mathrm{Na}}$, where $\mathrm{U}_{\mathrm{Na}}$ and $\mathrm{P}_{\mathrm{Na}}$ represent urinary and plasma sodium concentrations, respectively. V/GFR represents the fraction of the filtered water load excreted, $\mathrm{C}_{\mathrm{N} /} / \mathrm{GFR}$ the fraction of the filtered sodium load excreted, and $\mathrm{C}_{\mathrm{H}_{2} \mathrm{O}}$ /GFR the fraction of the filtered water load excreted as free water.

\section{Results}

Mannitol studies. As the rate of infusion of mannitol was increased, $\mathrm{V}, \mathrm{C}_{\mathrm{osm}}$, and $\mathrm{C}_{\mathrm{Na}}$ rose progressively (Table I, Figure 1). In all studies the rise in $\mathrm{V}, \mathrm{C}_{\mathrm{osm}}$, and $\mathrm{C}_{\mathrm{Na}}$ was associated initially with a progressive increase in $\mathrm{C}_{\mathrm{H}_{2} \mathrm{O}}$ (Table I, Figure 1). However, in two studies, late in the diuresis, $\mathrm{C}_{\mathbf{H}_{2} \mathrm{O}}$ tended to stabilize despite progressive increments in $\mathrm{V}, \mathrm{C}_{\mathrm{osm}}$, and $\mathrm{C}_{\mathrm{Na}}$ (Figure 1). In order to determine whether this tendency for $\mathrm{C}_{\mathrm{H}_{2} \mathrm{O}}$

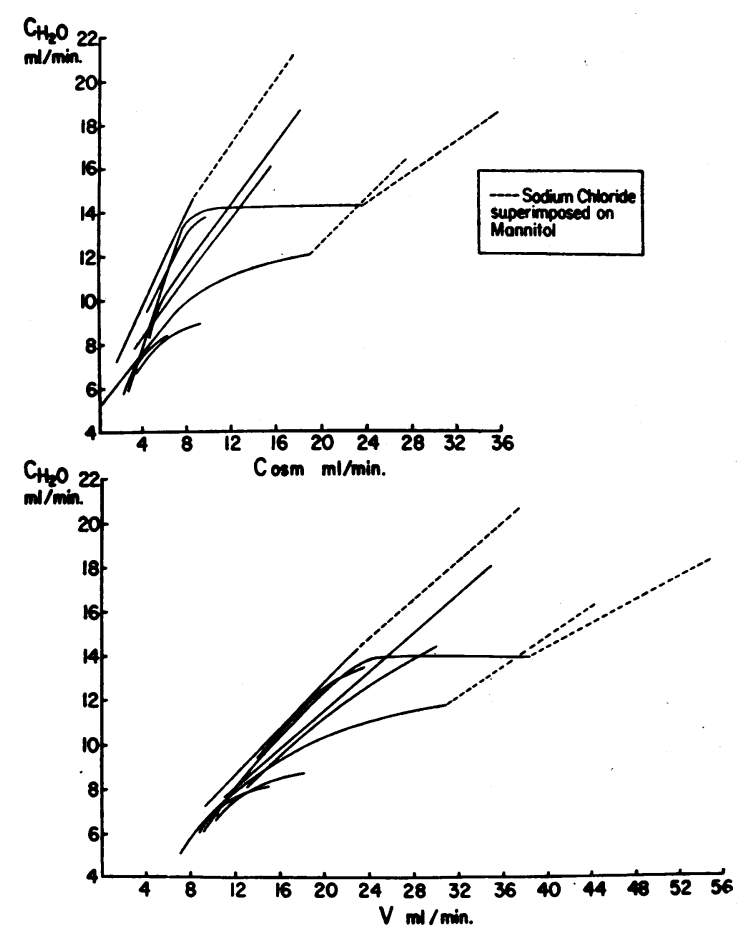

Fig. 1. UPPER FIGURE: EFFECTS OF HYPOTONIC MANNITOL LOADING ON THE RELATIONSHIP BETWEEN FREE WATER CLEARANCE $\left(\mathrm{C}_{\mathrm{H}_{20}}\right.$ ) AND SOlUte ClearanCE ( $\mathrm{C}_{\text {osm }}$ ) IN EIGHT EXPERIMENTS.

LOWER FIGURE : EFFECTS OF HYPOTONIC MANNITOL LOADING ON THE RELATIONSHIP BETWEEN $\mathrm{C}_{\mathrm{H}_{2} \mathrm{O}}$ AND URINE FLOW RATE (V) IN EIGHT EXPERIMENTS. In both upper and lower figures, the effects of an infusion of hypotonic saline superimposed on the mannitol diuresis are also depicted.

TABLE II

A typical saline loading experiment performed without renal arterial constriction (data from both kidneys)

\begin{tabular}{|c|c|c|c|c|c|c|c|c|c|c|c|c|}
\hline Time & V & Uosm & Cosm & $\mathrm{C}_{\mathrm{H}_{2} \mathrm{O}}$ & Cinulin & $\begin{array}{c}\text { (V/GFR) } \\
\times 100\end{array}$ & $\begin{array}{c}\text { (CHzO/GFR) } \\
\times 100\end{array}$ & $\mathrm{PN}_{\mathrm{N}}$ & $\mathrm{C}_{\mathrm{Na}}$ & $\begin{array}{c}\left(\mathrm{C}_{\mathrm{Na} / \mathrm{GFR}}\right) \\
\times 100\end{array}$ & $\begin{array}{l}\mathrm{C}_{\mathrm{HzO}} \\
+\mathrm{C}_{\mathrm{Na}}\end{array}$ & 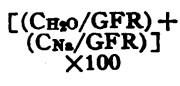 \\
\hline $\min$ & $m l / m i n$ & $\mathrm{mOsm} / \mathrm{kg}$ & $m l / \min$ & $m l / m i n$ & $m l / m i n$ & $\%$ & $\%$ & $m E q / L$ & $m l / m i n$ & $\%$ & $m l / m i n$ & $\%$ \\
\hline $\begin{array}{l}0 \\
60 \\
85-200\end{array}$ & \multicolumn{12}{|c|}{$\begin{array}{l}\text { Primes administered. Constant infusion started: inulin, } 50 \mathrm{mg} / \mathrm{min} \text { in } 0.45 \% \mathrm{NaCl} \text {, at } 1.0 \mathrm{ml} / \mathrm{min} \text {. } \\
\text { Surgery completed. } \\
0.45 \% \mathrm{NaCl} \text { administered at } 10 \mathrm{ml} / \mathrm{min} \text {. }\end{array}$} \\
\hline $200-215$ & 6.9 & 69 & 1.6 & 5.3 & 71 & 9.8 & 7.5 & 133 & 0.4 & 0.6 & 5.7 & 8.1 \\
\hline 215 & \multicolumn{12}{|c|}{$0.45 \% \mathrm{NaCl}$ administered at progressively increasing rates throughout the remainder of experiment. } \\
\hline 215-230 & 8.7 & 68 & 2.0 & 6.7 & 74 & 11.7 & 9.0 & 131 & 0.7 & 1.0 & 7.4 & 10.0 \\
\hline 230-245 & 10.0 & 70 & 2.4 & 7.6 & 75 & 13.4 & 10.2 & 131 & 1.0 & 1.3 & 8.6 & 11.5 \\
\hline $245-265$ & 11.6 & 75 & 2.9 & 8.7 & 71 & 16.3 & 12.2 & 131 & 1.5 & 2.1 & 10.2 & 14.3 \\
\hline $26 j-285$ & 13.0 & 82 & 3.5 & 9.5 & 65 & 20.1 & 14.6 & 130 & 2.1 & 3.3 & 11.6 & 17.9 \\
\hline $285-305$ & 15.0 & 90 & 4.5 & 10.5 & 75 & 20.0 & 14.0 & 131 & 3.0 & 4.0 & 13.5 & 18.0 \\
\hline $305-325$ & 17.0 & 108 & 6.1 & 10.9 & 72 & 23.6 & 15.1 & 131 & 4.6 & 6.4 & 15.5 & 21.5 \\
\hline $325-345$ & 18.3 & 119 & 7.2 & 11.1 & 74 & 24.6 & 14.9 & 131 & 6.1 & 8.2 & 17.2 & 23.1 \\
\hline $345-365$ & 19.3 & 134 & 8.6 & 10.7 & 74 & 26.1 & 14.5 & 131 & 7.3 & 9.9 & 18.0 & 24.4 \\
\hline $365-385$ & 20.9 & 145 & 10.0 & 10.9 & 74 & 28.2 & 14.7 & 131 & 9.0 & 12.1 & 19.9 & 26.8 \\
\hline $385-405$ & 22.8 & 152 & 11.3 & 11.5 & 69 & 32.6 & 16.4 & 129 & 11.1 & 16.0 & 22.6 & 32.4 \\
\hline $405-425$ & 23.2 & 154 & 11.7 & 11.5 & 69 & 33.7 & 16.7 & 129 & 11.5 & 16.7 & 23.0 & 33.4 \\
\hline $425-445$ & 25.0 & 163 & 13.4 & 11.6 & 72 & 34.7 & $16.1^{\prime}$ & 129 & 13.3 & 18.5 & 24.9 & 34.6 \\
\hline $445-465$ & 27.7 & 175 & 15.9 & 11.8 & 73 & 38.0 & 16.2 & 129 & 15.8 & 21.7 & 27.6 & 37.9 \\
\hline $465-485$ & 28.9 & 183 & 17.5 & 11.4 & 73 & 39.6 & 15.6 & 129 & 17.2 & 23.6 & 28.6 & 39.2 \\
\hline
\end{tabular}


TABLE III

A typical saline loading experiment in which one renal artery was constricted (data from the control kidney)

\begin{tabular}{|c|c|c|c|c|c|c|c|c|c|c|c|c|}
\hline Time & V & Uosm & Cosm & $\mathrm{C}_{\mathrm{H}_{2} \mathrm{O}}$ & Cinulin & $\begin{array}{c}(\text { V/GFR) } \\
\times 100\end{array}$ & $\begin{array}{c}\left(\mathrm{C}_{\mathrm{HzO}} / \mathrm{GFR}\right) \\
\times 100\end{array}$ & $\mathrm{P}_{\mathrm{Na}}$ & $\mathrm{C}_{\mathrm{Na}}$ & $\stackrel{\left(\mathrm{C}_{\mathrm{Na}} / \mathrm{GFR}\right)}{\times 100}$ & $\begin{array}{l}\mathrm{C}_{\mathrm{H} 2 \mathrm{O}} \\
+\mathrm{C}_{\mathrm{Na}}\end{array}$ & $\begin{array}{c}{\left[\left(\mathrm{CH}_{\mathrm{HzO}} / \mathrm{GFR}\right)+\right.} \\
\left.\left(\mathrm{C}_{\mathrm{Na}} / \mathrm{GFR}\right)\right] \\
\times 100\end{array}$ \\
\hline $\min$ & $\mathrm{ml} / \mathrm{min}$ & $\mathrm{mOsm} / \mathrm{kg}$ & $\mathrm{ml} / \mathrm{min}$ & $\mathrm{ml} / \mathrm{min}$ & $\mathrm{ml} / \mathrm{min}$ & $\%$ & $\%$ & $m E q / L$ & $m l / \min$ & $\%$ & $\mathrm{ml} / \mathrm{min}$ & $\%$ \\
\hline $\begin{array}{l}0 \\
60 \\
80-190\end{array}$ & \multicolumn{12}{|c|}{$\begin{array}{l}\text { Surgery completed. } \\
0.45 \% \mathrm{NaCl} \text { administered at } 10 \mathrm{ml} / \mathrm{min} \text {. }\end{array}$} \\
\hline $190-200$ & 4.2 & 95 & 1.4 & 2.8 & 32 & 13.3 & 9.0 & 133 & 0.8 & 2.5 & 3.6 & 11.5 \\
\hline $200-210$ & 4.5 & 92 & 1.4 & 3.1 & 33 & 13.7 & 9.3 & 134 & 0.7 & 2.1 & 3.8 & 11.4 \\
\hline $210-260$ & \multicolumn{12}{|c|}{ Constriction of contralateral renal artery. } \\
\hline 260 & \multicolumn{12}{|c|}{$0.45 \% \mathrm{NaCl}$ administered at progressively increasing rates throughout the remainder of the experiment. } \\
\hline 260-270 & 7.1 & 115 & 2.8 & 4.3 & 38 & 18.8 & 11.3 & 133 & 2.0 & 5.1 & 6.3 & 16.4 \\
\hline 270-280 & 7.5 & 119 & 3.1 & 4.4 & 34 & 22.1 & 13.0 & 132 & 2.2 & 6.6 & 6.6 & 19.6 \\
\hline $280-290$ & 8.2 & 125 & 3.5 & 4.7 & 34 & 24.1 & 13.7 & 131 & 2.7 & 7.9 & 7.4 & 21.6 \\
\hline $290-300$ & 8.6 & 130 & 3.9 & 4.7 & 32 & 26.9 & 14.8 & 130 & 3.1 & 9.7 & 7.8 & 24.5 \\
\hline $300-310$ & 9.5 & 141 & 4.6 & 4.9 & 35 & 27.1 & 14.0 & 130 & 3.9 & 11.1 & 8.8 & 25.1 \\
\hline $310-320$ & 10.7 & 158 & 5.8 & 4.9 & 37 & 28.9 & 13.4 & 130 & 4.9 & 13.1 & 9.8 & 26.5 \\
\hline $320-330$ & 10.5 & 157 & 5.6 & 4.9 & 36 & 29.1 & 13.7 & 134 & 4.8 & 13.3 & 9.7 & 27.0 \\
\hline $330-340$ & 11.2 & 168 & 6.4 & 4.8 & 36 & 31.1 & 13.4 & 134 & 5.4 & 15.0 & 10.2 & 28.4 \\
\hline $340-350$ & 11.5 & 172 & 6.7 & 4.8 & 34 & 33.8 & 14.2 & 134 & 6.0 & 17.6 & 10.8 & 31.8 \\
\hline $350-360$ & 12.3 & 178 & 7.5 & 4.8 & 35 & 35.2 & 13.9 & 134 & 6.7 & 19.2 & 11.5 & 33.1 \\
\hline $360-370$ & 13.1 & 184 & 8.3 & 4.8 & 34 & 38.6 & 14.3 & 134 & 7.3 & 21.4 & 12.1 & 35.7 \\
\hline $370-380$ & 14.6 & 193 & 9.7 & 4.9 & 36 & 40.6 & 13.8 & 133 & 8.7 & 24.0 & 13.6 & 37.8 \\
\hline $380-390$ & 15.5 & 196 & 10.4 & 5.1 & 36 & 42.9 & 14.2 & 133 & 9.6 & 26.8 & 14.7 & 41.0 \\
\hline $390-400$ & 15.8 & 197 & 10.7 & 5.1 & 39 & 40.6 & 13.1 & 133 & 11.1 & 25.9 & 16.2 & 39.0 \\
\hline
\end{tabular}

to stabilize was consequent to a limit on the capacity to increase $\mathrm{C}_{\mathrm{H}_{2} \mathrm{O}}$, we administered acetazolamide or a rapid infusion of hypotonic $(0.45 \%)$ saline during the course of several mannitol studies at high levels of urine flow (Figure 1). The administration of acetazolamide provoked a modest rise in $\mathrm{C}_{\mathrm{H}_{2} \mathrm{O}}$ as V, $\mathrm{C}_{\mathrm{Osm}}$, and $\mathrm{C}_{\mathrm{Na}}$ increased. Since
GFR fell in these studies $\mathrm{C}_{\mathrm{H}_{2} \mathrm{O}} / \mathrm{GFR}$ rose sharply. When a hypotonic saline infusion was superimposed on the mannitol diuresis, GFR remained unchanged, and as $\mathrm{V}, \mathrm{C}_{\mathrm{osm}}$, and $\mathrm{C}_{\mathrm{Na}}$ rose, a striking increase in $\mathrm{C}_{\mathrm{H}_{2} \mathrm{O}}$ was noted (Figure 1). Although $\mathrm{V}$ could be increased to $50 \%$ of the filtered load during these mannitol studies, a limit in the ca-

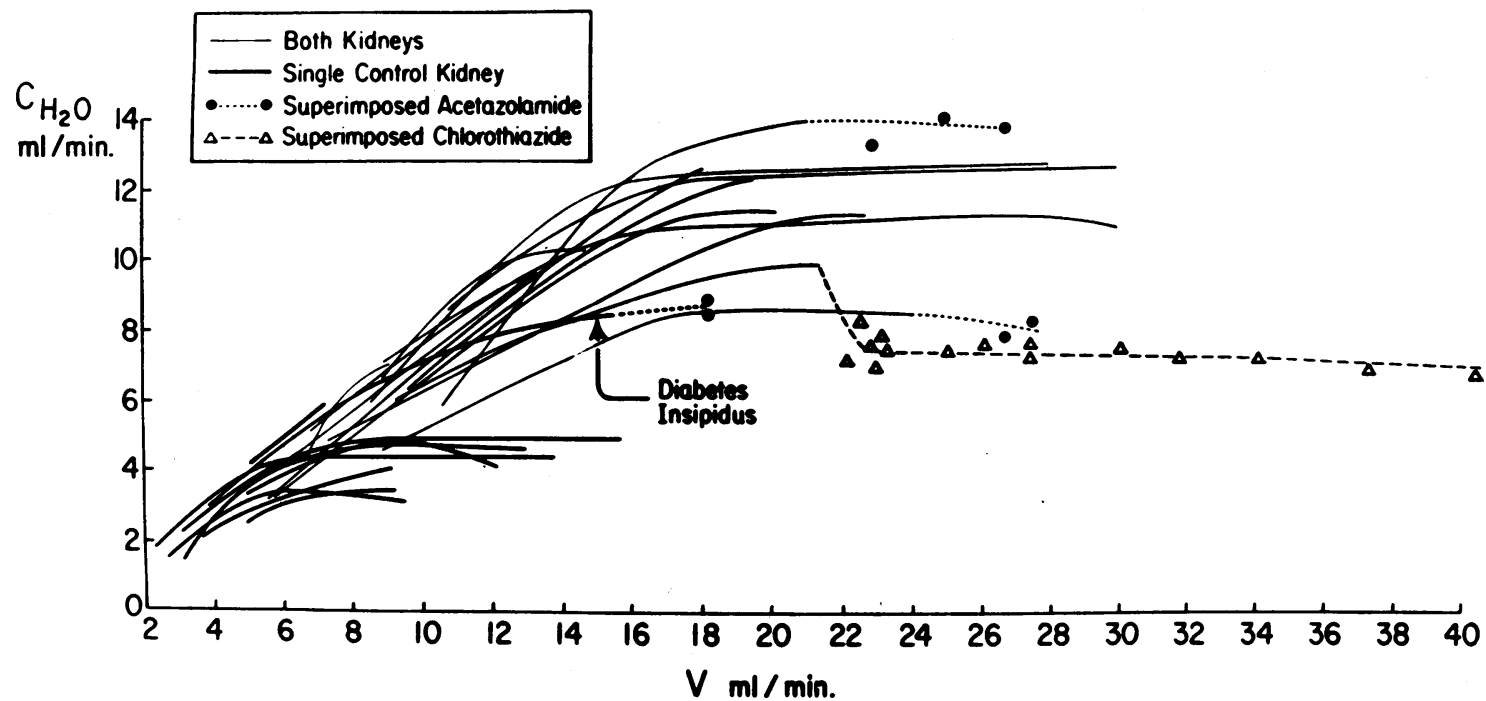

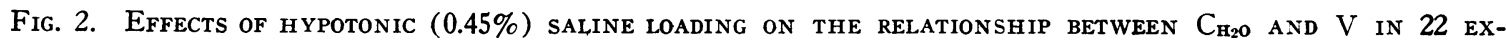
PERIMENTS. In 15 experiments, data were obtained from two kidneys, whereas in 7 experiments in which one renal artery was constricted, data were obtained from one control kidney. The effects of acetazolamide or chlorothiazide superimposed on the saline diuresis are also depicted. 
pacity to increase $\mathrm{C}_{\mathrm{H}_{2} \mathrm{O}}$ could not be demonstrated (Figure 1). Levels of $\mathrm{C}_{\mathrm{H}_{2} \mathrm{O}}$ in excess of $25 \%$ of the filtered load were observed in several studies.

Saline studies. Early in the course of saline loading, $\mathrm{C}_{\mathrm{H}_{2} \mathrm{O}}$ rose sharply with small increments in V, $\mathrm{C}_{\mathrm{osm}}$, and $\mathrm{C}_{\mathrm{Na}}$ (Tables II, III, and Figures $2,3){ }^{1}$ In those studies in which $\mathrm{V}$ could be increased beyond 20 to $25 \%$ of the filtered load, $\mathrm{C}_{\mathrm{H}_{2} \mathrm{O}}$ attained maximal levels and tended to remain relatively stable as $\mathrm{V}$ increased to $48 \%$ of the filtered load (Tables II, III and Figure 3). It was noted that $\mathrm{C}_{\mathrm{H}_{2} \mathrm{O}}$ generally stabilized after $\mathrm{C}_{\mathrm{Na}}$ increased to 4 to $8 \%$ of the filtered load and remained stable as $\mathrm{C}_{\mathrm{Na}}$ rose to $30 \%$ of the filtered load (Tables II, III). The level at which $\mathrm{C}_{\mathrm{H}_{2} \mathrm{O}}$ stabilized averaged approximately $15 \%$ of the filtered load (Figure 3). In contrast to the mannitol studies, $\mathrm{C}_{\mathrm{H}_{2} \mathrm{O}}$ levels above $20 \%$ of the filtered load were not found (Figure 3 ). At the time $\mathrm{C}_{\mathrm{H}_{2} \mathrm{O}}$ stabi-

1 Glomerular filtration rate remained relatively stable throughout each study. In some experiments, however, results represent data obtained from both kidneys, whereas in other experiments results represent data obtained from one control kidney. It is apparent, therefore, that a wide range of GFR was encountered. In order to obtain a uniform presentataion of data, $\mathrm{V}, \mathrm{C}_{\mathrm{Na}}$, and $\mathrm{C}_{\mathrm{H}_{2} \mathrm{O}}$ have been factored by GFR. lized, dogs had received intravenously 85 to $220 \mathrm{ml}$ per $\mathrm{kg}$ body weight of $0.45 \% \mathrm{NaCl}$. An additional study was performed on an unanesthetized dog with diabetes insipidus whose urinary osmolality after 16 hours of dehydration was 58 mOsm per $\mathrm{kg} \mathrm{H}_{2} \mathrm{O}$. Results otbained from this study were similar to those obtained from other saline studies (Figures 2, 3).

In several experiments, acetazolamide was administered during the saline diuresis after $\mathrm{C}_{\mathrm{H}_{2} \mathrm{O}}$ had stabilized. Despite further increments in V, $\mathrm{C}_{\mathrm{osm}}$, and $\mathrm{C}_{\mathrm{Na}}$ produced by this agent, $\mathrm{C}_{\mathrm{H}_{2} \mathrm{O}}$ and $\mathrm{C}_{\mathrm{H}_{2} \mathrm{O}}$ /GFR could not be appreciably increased (Figures 2, 3). In another study a constant infusion of chlorothiazide was superimposed on the increasing saline diuresis. Initially, $\mathrm{C}_{\mathrm{H}_{2} \mathrm{O}}$ fell; thereafter it remained relatively stable as $\mathrm{V}$ increased from 32 to $48 \%$ of the filtered load (Figures 2, 3).

Early in the course of several saline loading experiments, a reduction in GFR was produced in one kidney by unilateral renal arterial constriction. Associated with the reduction in GFR in the experimental kidney, $\mathrm{C}_{\text {osm }}, \mathrm{C}_{\mathrm{Na}}$, and $\mathrm{C}_{\mathrm{H}_{2} \mathrm{O}}$ fell (Figure 4, $a$ and $b$ ). Thereafter, as the saline load was increased, $\mathrm{C}_{\mathrm{osm}}$ and $\mathrm{C}_{\mathrm{Na}}$ rose progressively in both

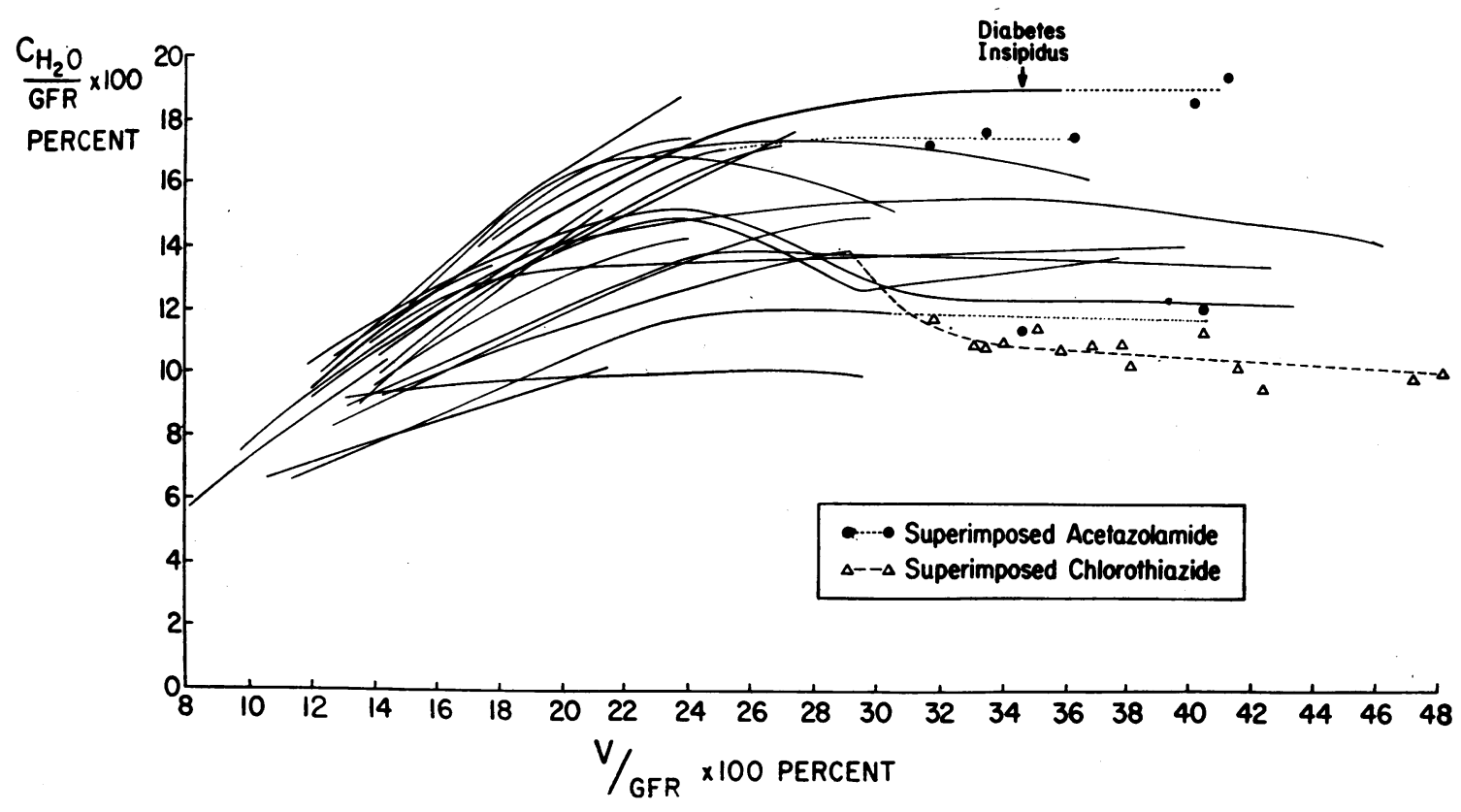

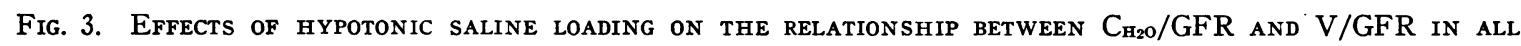
EXPERIMENTS. The effects of acetazolamide or chlorathiazide superimposed on the saline diuresis are also depicted. $\mathrm{GFR}=$ glomerular filtration rate. 

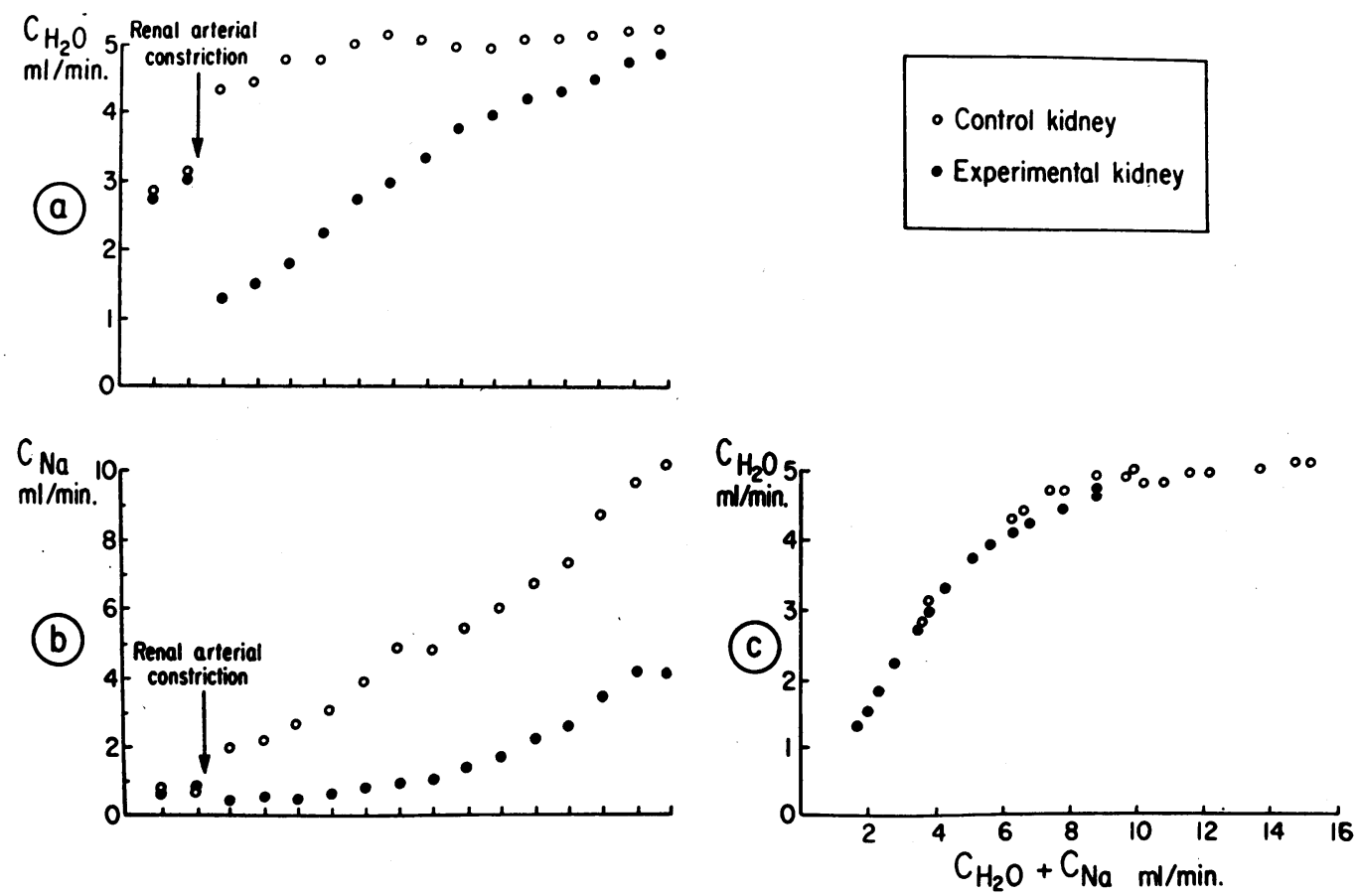

Fig. 4. Effects of unilateral Renal arterial constriction on (a) C $_{\mathrm{H}_{2} \mathrm{O}}$ and (B) sodium clearANCE $\left(\mathrm{C}_{\mathrm{Na}}\right)$ DURING A HYPOTONIC SALINE LOADING EXPERIMENT. The vertical bars on the abscissa represent successive collection periods obtained during the study.

(c) Effects of hypotonic Saline loading on the Relationship between $\mathrm{C}_{\mathrm{H}_{2} \mathrm{O}}$ and $\mathrm{C}_{\mathrm{H}_{2} \mathrm{O}}+\mathrm{C}_{\mathrm{Na}}$ in the CONTROL AND CONSTRICTED KIDNEYS.

kidneys (Figure 4, b). In the control kidney, $\mathrm{C}_{\mathrm{H}_{2} \mathrm{O}}$ stabilized relatively early in the course of the study, whereas it continued to rise for a considerable time in the experimental kidney (Figure 4, a). Although $\mathrm{C}_{\mathrm{H}_{2} \mathrm{O}}$ stabilized at different times in the two kidneys, $\mathrm{C}_{\mathrm{H}_{2} \mathrm{O}}$ per level of $\mathrm{V}$ or $\mathrm{C}_{\mathrm{H}_{2} \mathrm{O}}+$ $\mathrm{C}_{\mathrm{Na}}$ was similar in the two kidneys (Figure $4, \mathrm{c}$ ).

\section{Discussion}

It is generally accepted that the production of dilute urine depends on the transport of sodium without water at the ascending limb of the loop of Henle and probably at more distal tubular sites. In numerous studies performed under hydrated conditions, the rate of formation of solute-free water has been utilized as an index of the rate of sodium transport at these distal water-clearing sites. The increase in $\mathrm{C}_{\mathrm{H}_{2} \mathrm{O}}$ during a solute diuresis has, therefore, been ascribed to a progressive rise in distal sodium supply and transport $(1,6$ 10). Alternatively, it has been suggested that the rise in $\mathrm{C}_{\mathrm{H}_{2} \mathrm{O}}$ may be due to a progressive decrease in the back diffusion of water at distal sites as a consequence of an increased excretion of nonreabsorbed solute (11). It has been demonstrated, however, in the present and previous studies that $\mathrm{C}_{\mathrm{H}_{2} \mathrm{O}}$ may remain stable over a wide range of $\mathrm{C}_{\mathrm{osm}}$ during a solute diuresis (Figures 1,2) $(6,12,13)$. Moreover, $\mathrm{C}_{\mathrm{H}_{2} \mathrm{O}}$ may be subsequently increased when additional sodium is presented to the distal tubule (Figure 1) $(6,13)$. The absence of a consistent relationship between $\mathrm{C}_{\mathrm{H}_{2} \mathrm{O}}$ and $\mathrm{C}_{\mathrm{osm}}$ suggests that changes in $\mathrm{C}_{\mathrm{H}_{2} \mathrm{O}}$ do not depend primarily on altered rates of distal back diffusion of water. Other investigators have also found it difficult to ascribe the major increase in $\mathrm{C}_{\mathrm{H}_{2} \mathrm{O}}$ to a diminished distal back diffusion of water $(7,8)$. It seems reasonable to assume, therefore, that changes in $\mathrm{C}_{\mathrm{H}_{2} \mathrm{O}}$ represent an index of changes in the rate of sodium transport at distal water-clearing sites. In this context, changes in $\mathrm{C}_{\mathrm{H}_{2} \mathrm{O}}+\mathrm{C}_{\mathrm{Na}}$ provide an estimate of changes in the rate of delivery of sodium to distal sites $(8,9,14)$, and $V$, an index of the quantity of isosmotic fluid that escapes proximal reabsorption $(1,7)$.

It is well established that mannitol loading de- 
creases proximal tubular sodium reabsorption. The rise in $\mathrm{C}_{\mathrm{H}_{2} \mathrm{O}}$ noted in the present mannitol studies would suggest that as distal sodium supply $\left(\mathrm{C}_{\mathrm{H}_{2} \mathrm{O}}+\mathrm{C}_{\mathrm{Na}}\right)$ rises during mannitol loading, the distal tubule progressively increases its rate of sodium transport (Table I, Figure 1). In several studies, including the two in which $\mathrm{C}_{\mathrm{H}_{2} \mathrm{O}}$ tended to stabilize, a further inhibition of proximal sodium reabsorption was obtained by superimposing acetazolamide or an infusion of hypotonic saline on the mannitol diuresis (Figure 1) $(1,2,15,16)$. Associated with the sharp rise in the quantity and concentration of sodium delivered to distal sites in these studies, distal sodium transport increased progressively (Figure 1). Thus, the present studies fail to demonstrate a maximal rate of distal sodium transport during mannitol loading.

The occasional failure of $\mathrm{C}_{\mathrm{H}_{2} \mathrm{O}}$ to rise progressively during mannitol loading may be consequent to a substantial fall in the concentration of sodium in the tubular fluid presented to distal sites. At high distal flow rates, a reduced intratubular sodium concentration may limit the capacity of the ascending limb to increase its rate of transport (17). If the concentration of sodium reaching distal sites falls sufficiently, the rate of delivery of sodium to the ascending limb may actually fail to increase. In this case, an increase in sodium excretion without a change in $\mathrm{C}_{\mathrm{H}_{2} \mathrm{O}}$ could derive from an inhibition of isosmotic sodium transport at a distal tubular site $(6,18)$. Regardless of the factors responsible for the occasional tendency of $\mathrm{C}_{\mathrm{H}_{2} \mathrm{O}}$ to stabilize, the present, as well as previous, studies provide no evidence to suggest a transport limit for sodium at the ascending limb during mannitol loading (Figure 1) $(8,10,17,19)$.

During saline loading, $\mathrm{C}_{\mathrm{H}_{2} \mathrm{O}}$ initially rose sharply as $\mathrm{V}, \mathrm{C}_{\mathrm{osm}}$, and $\mathrm{C}_{\mathrm{Na}}$ increased (Tables II, III, Figures 2,3). This finding is consistent with the proposal that hypotonic saline loading inhibits proximal sodium reabsorption and thereby increases distal sodium supply and transport $(1,2)$. At distal flow rates greater than $20 \%$ of the filtered load, $\mathrm{C}_{\mathrm{H}_{2} \mathrm{O}}$ rose more slowly, attained maximal levels, and thereafter remained relatively stable as distal flow rate and distal sodium supply increased from approximately 25 to $50 \%$ of the filtered load (Tables II, III, Figure 3). In addition, when distal sodium supply was further increased late in the diuresis by the administration of acetazolamide, distal sodium transport could not be increased (Figures 2,3). It would appear, therefore, that during hypotonic saline loading sodium transport in the distal tubule is limited by a maximal rate (Tables II, III, and Figures 2 , 3 ). This limit permits the reabsorption of up to $20 \%$ of the filtered load at distal sites (Figure 3 ). The data obtained during saline loading contrast with those obtained during mannitol loading, where no limit on distal sodium transport could be demonstrated despite comparable rates of distal water and sodium supply (Figure 5).

Alternatively, it is possible that ascending limb sodium transport increases without limit during saline loading. The increased deposition of solute within the medulla might result in sufficient outward diffusion of water from the descending limb of Henle's loop to prevent a progressive rise in $\mathrm{C}_{\mathrm{H}_{2} \mathrm{O}}$. This proposal would imply that early in the saline diuresis the rate of descending limb

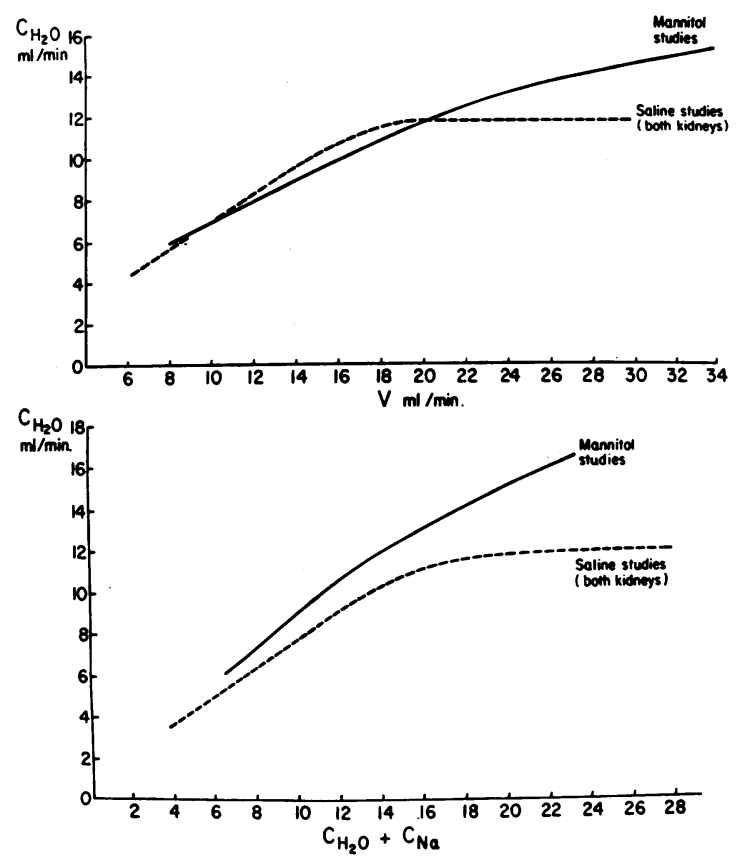

FIG. 5. UPPER FIGURE: COMPARISON OF THE EFFECTS OF HYPOTONIC MANNITOL AND HYPOTONIC SALINE LOADING ON THE RELATIONSHIP BETWEEN $\mathrm{C}_{\mathrm{H}_{2} \mathrm{O}}$ AND V.

LOWER FIGURE: COMPARISON OF THE EFFECTS OF HYPOTONIC MANNITOL AND HYPOTONIC SALINE LOADING ON THE RELATIONSHIP BETWEeN $\mathrm{C}_{\mathrm{H}_{2} \mathrm{O}}$ AND $\mathrm{C}_{\mathrm{H} 2 \mathrm{O}}+\mathrm{C}_{\mathrm{Na}}$. Both upper and lower figures depict mean curves obtained from all mannitol studies and mean curves obtained from those saline studies in which there was no renal arterial constriction. 
water loss would lag behind that of ascending limb sodium transport, permitting $\mathrm{C}_{\mathrm{H}_{2} \mathrm{O}}$ to rise. Comparable increments in ascending limb transport late in the diuresis, however, would provoke the outward diffusion of relatively larger quantities of water, nullifying a further increase in $\mathrm{C}_{\mathrm{H}_{2} \mathrm{O}}$. In contrast, during mannitol loading or after a saline load was superimposed on a mannitol diuresis, water loss from the descending limb would remain consistently insufficient to prevent the rise in $\mathrm{C}_{\mathrm{H}_{2} \mathrm{O}}$. The need to postulate that comparable increments in ascending limb sodium transport provoke variable rates of water movement from the descending limb would tend to exclude this alternative proposal. Moreover, implicit-in this hypothesis is the additional assumption that virtually all $\mathrm{C}_{\mathrm{H}_{2} \mathrm{O}}$ is formed in those portions of the nephron located within the medulla. Several studies, however, suggest that segments of the tubule outside of the medulla may contribute appreciably to $\mathrm{C}_{\mathrm{H}_{2} \mathrm{O}}$ formation $(15,20,21)$. Thus, it seems more reasonable to conclude that the limit on $\mathrm{C}_{\mathrm{H}_{2} \mathrm{O}}$ formation during saline loading is consequent to a limit on distal sodium transport.

In the experiments in which a unilateral reduction in GFR was produced, maximal $\mathrm{C}_{\mathrm{H}_{2} \mathrm{O}}$ levels were obtained early in the study on the control kidney, whereas $\mathrm{C}_{\mathrm{H}_{2} \mathrm{O}}$ continued to rise for a considerable time in the experimental kidney (Figure $4, \mathrm{a})$. However, $\mathrm{C}_{\mathrm{H}_{2} \mathrm{O}}$ or distal sodium transport stabilized in each kidney at a comparable level of distal sodium supply (Figure 4, c). These experiments reveal that the distal transport limit that appears during saline loading cannot be clearly demonstrated until distal sodium supply exceeds critical levels (approximately 25\% of the filtered load) (Tables II, III, and Figures 3, 5).

A further comparison of the mannitol and saline studies suggests, however, that an alteration in distal transport may develop during saline loading before the distal limit becomes manifest. Since mannitol is a nonreabsorbable solute it is apparent that at every level of distal solute supply (V) during mannitol and saline loading the rate of delivery of absorbable solute (sodium) to distal sites would be lower during mannitol loading. The finding that $\mathrm{C}_{\mathrm{H}_{2} \mathrm{O}}$ per $\mathrm{V}$ was initially similar during mannitol and saline loading (Figure 5) suggests, therefore, that even at low distal flow rates, saline loading reduces the fraction of the sodium supply reabsorbed in the distal tubule (Figure 6).

The present studies may help to reconcile the conflicting conclusions regarding the tubular sites of altered sodium transport during saline loading in $\operatorname{dog}(1-4)$. Saline loading apparently provokes a progressive inhibition of proximal sodium reabsorption $(1,2)$. Initially, the distal tubule absorbs a large fraction of the proximal rejectate (Figure 6 ), as reflected by the sharp rise in $\mathrm{C}_{\mathrm{H}_{2} \mathrm{O}}$ with only modest increases in sodium excretion

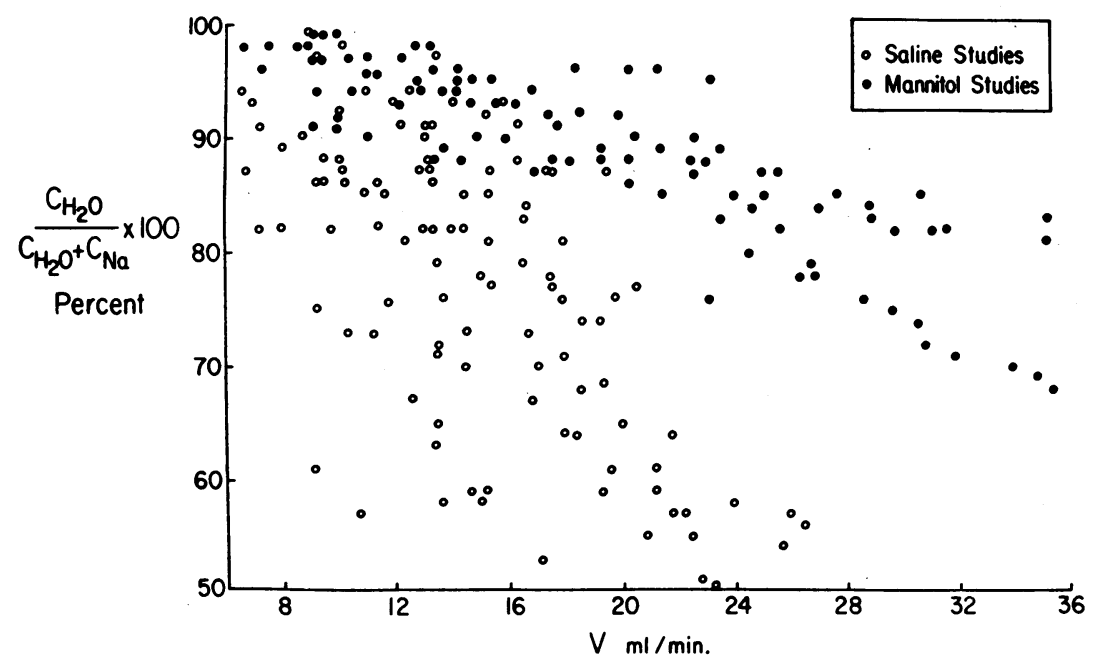

Fig. 6. COMPARISON OF THE EFFECTS OF HYPOTONIC MANNITOL AND HYPOTONIC SALINE LOADING ON $\mathrm{C}_{\mathrm{H}_{2} \mathrm{O}} / \mathrm{C}_{\mathrm{H}_{2} \mathrm{O}}+\mathrm{C}_{\mathrm{Na}}$ (AN INDEX OF THE FRACTION OF THE DISTAL SODIUM SUPPLY ABSORBED IN THE DISTAL TUBULE) AT ALL LEVELS OF V. 
(Tables II, III). Thereafter, a progressive alteration in distal sodium reabsorption appears to develop (Figure 6) $(3,4)$, which culminates in a maximal rate of distal sodium transport (Figures $2-5)$. It is during this phase of altered distal sodium transport that the major increment in sodium excretion develops (Tables II, III).

The limit on distal sodium transport evident during saline loading does not appear to represent an inherent tubular transport maximum for sodium as described for glucose. As previously stated, no such maximum could be demonstrated during mannitol loading (Figures 1, 5). Moreover, the finding that during saline loading sodium excretion may increase appreciably before the distal limit becomes evident also suggests that this limit clearly differs from a classical Tm ( Tables II, III).

The limit on net distal sodium transport might result from a balance of increasing and decreasing sodium reabsorption at separate water-clearing sites (13). It seems unlikely, however, that such a balance would remain unaltered over an extensive range of distal flow rates (from 25 to $50 \%$ of the filtered load). Moreover, a sustained decrease in transport at one of these sites would be expected to disrupt this balance and alter the stability of $\mathrm{C}_{\mathrm{H}_{2} \mathrm{O}}$ (13). The failure of the sustained inhibition of distal transport induced by thiazide $(15,16,22)$ to alter the stability of $\mathrm{C}_{\mathrm{H}_{2} \mathrm{O}}$ during the subsequent saline diuresis (Figures 2, 3) is, therefore, difficult to reconcile with the proposal of a balance of distal effects (13).

It has been previously suggested that under hydrated conditions sodium and water may be reabsorbed in the distal tubule in isosmotic proportions $(6,18)$. A fraction of the rise in $\mathrm{C}_{\text {osm }}$ or $\mathrm{V}$ without any change in $\mathrm{C}_{\mathrm{H}_{2} \mathrm{O}}$ might result from an inhibition of sodium transport at such a distal segment (6), but the extent, if any, to which this occurs could not be evaluated.

The present experiments may permit an analysis of several factors that affect tubular function during saline loading in dog. The mannitol studies demonstrate that increasing distal flow rates, per se, do not limit sodium transport in the distal tubule. Therefore, changes in tubular geometry consequent to high distal flow rates do not appear to be responsible for the distal effect evident during saline loading. It would appear, instead, that through an unknown mechanism saline loading imposes a limit on distal sodium transport that may not exist under other conditions. In any event, the major increment in salt excretion provoked by saline loading apparently develops only after saline alters the capacity of the distal tubule to transport sodium.

\section{Acknowledgments}

We gratefully acknowledge the valuable assistance of Dr. Michael Kinney in the performance of several experiments; the technical assistance of Mrs. Edith Neubert, Miss Sarah Chipoco, and Miss Lois Lucas; and the assistance of Miss Dorothy Abraham in the preparation of the manuscript.

\section{References}

1. Rector, F. C., Jr., G. Van Giesen, F. Kiil, and D. W. Seldin. Influence of expansion of extracellular volume on tubular reabsorption of sodium independent of changes in glomerular filtration rate and aldosterone activity. J. clin. Invest. 1964, 43, 341.

2. Dirks, J. H., W. J. Cirksena, and R. W. Berliner. The effect of saline infusion on sodium reabsorption by the proximal tubule of the dog. J. clin. Invest. 1965, 44, 1160.

3. Stein, R. M., D. D. Bercovitch, and M. F. Levitt. Dual effects of saline loading on renal tubular sodium reabsorption in the dog. Amer. J. Physiol. 1964, 207, 826.

4. Earley, L. E., and R. M. Friedler. Observations on the mechanism of decreased tubular reabsorption of sodium and water during saline loading. J. clin. Invest. 1964, 43, 1928.

5. Smith, H. W. Principles of Renal Physiology. New York, Oxford University Press, 1956, p. 210.

6. Goldstein, M. H., M. F. Levitt, A. D. Hauser, and D. Polimeros. Effect of meralluride on solute and water excretion in hydrated man: comments on site of action. J. clin. Invest. 1961, 40, 731.

7. Van Giesen, G., M. Reese, F. Kiil, F. C. Rector, Jr., and D. W. Seldin. The characteristics of renal hypoperfusion in dogs with acute and chronic reductions in glomerular filtration rate as disclosed by the pattern of water and solute excretion after hypotonic saline infusions. J. clin. Invest. 1964, 43, 416.

8. Steinmetz, P. R., R. P. Eisinger, E. A. Gombos, H. Chasis, and D. S. Baldwin. Excretion of free water and solute during maximal water diuresis in normal and hypertensive subjects. J. Lab. clin. Med. 1964, 64, 238.

9. Stein, R. M., R. G. Abramson, D. D. Bercovitch, and M. F. Levitt. Effects of unilateral renal arterial 
constriction on tubular reabsorption of sodium and water during an osmotic diuresis. J. clin. Invest. 1965, 44, 1720.

10. Becker, E. L., and H. E. Ginn. Free water excretion in normal dogs. Amer. J. Physiol. 1962, 202, 1131.

11. Orloff, J., H. N. Wagner, Jr., and D. G. Davidson. The effect of variations in solute excretion and vasopressin dosage on the excretion of water in the dog. J. clin. Invest. 1958, 37, 458.

12. Orloff, J., and M. Walser. Water and solute excretion in pitressin-resistant diabetes insipidus (abstract). Clin. Res. 1956, 4, 136.

13. Goldberg, M., B. R. Walker, and V. M. Buckalew, Jr. Response of renal diluting sites to saline loading in man (abstract). J. clin. Invest. 1966, 45, 1013.

14. Laragh, J. H., P. J. Cannon, C. J. Bentzel, A. M. Sicinski, and J. I. Meltzer. Angiotensin II, norepinephrine, and renal transport of electrolytes and water in normal man and in cirrhosis with ascites. J. clin. Invest. 1963, 42, 1179.

15. Earley, L. E., M. Kahn, and J. Orloff. The effects of infusions of chlorothiazide on urinary dilution and concentration in the dog. J. clin. Invest. 1961, 40, 857 .
16. Dirks, J. H., W. J. Cirksena, and R. W. Berliner Micropuncture study on the effect of various diuretics on sodium reabsorption by the proximal tubule of the dog. Clin. Res. 1965, 13, 553.

17. Goldberg, M., D. K. McCurdy, and M. A. Ramirez. Differences between saline and mannitol diuresis in hydropenic man. J. clin. Invest. 1965, 44, 182.

18. Seldin, D. W., G. Eknoyan, W. N. Suki, and F. C. Rector, Jr. Localization of diuretic action from the pattern of water and electrolyte excretion. Ann. N. Y. Acad. Sci. 1966, 139, 328.

19. Giebisch, G., and E. E. Windhager. Renal tubular transfer of sodium, chloride and potassium. Amer. J. Med. 1964, 36, 643.

20. Goldberg, M., D. K. McCurdy, E. L. Foltz, and L. W. Bluemle, Jr. Effects of ethacrynic acid (a new saluretic agent) on renal diluting and concentrating mechanisms: evidence for site of action in the loop of Henle. J. clin. Invest. 1964, 43, 201.

21. Earley, L. E., and R. M. Friedler. Renal tubular effects of ethacrynic acid. J. clin. Invest. 1964, 43, 1495.

22. Heinemann, H. D., F. E. Demartini, and J. H. Laragh. The effect of chlorothiazide on renal excretion of electrolytes and free water. Amer. J. Med. 1959, 26, 853. 